\title{
The Innovation and Practice of English and American Literature Teaching Model in We-Media Environment
}

\author{
Baiping Huang \\ Pingxiang University, Pingxiang, Jiangxi, 337055, China
}

\begin{abstract}
Keywords: English and American Literature; Teaching model; We-media; Network technology
\end{abstract}
\begin{abstract}
This paper briefly introduces the construction of English and American literature teaching model in we-media environment, including the in classroom teaching for teachers and the out of classroom self-leaning for students. An investigation on the current situation of English and American literature courses for English major students shows where the causes of the marginalization of English and American literature curriculum lie. Thus the creative teaching reform is put forward based on the media and the network. This paper serves to analyze the current situation of English and American literature learning in English colleges and universities in China. What's more, this research provides reference for the teaching reform of the course and promotes the secondary development and utilization of English and American literature courses.
\end{abstract}

\section{Introduction}

English and American literature course is one of the main courses for senior English students with a certain English language basis. The course is designed to cultivate students' ability to appreciate the essence of English literature, to deepen students' understanding of English culture and language and to improve students' cross-cultural communicative ability at the same time. However, many colleges and universities focus on the curriculum to the translation, listening, oral and other practical English courses due to the impact of pragmatism. The substantial reduction in English and American literature courses and the traditional teaching methods for some college teachers have put English and American literature into a low-quality and marginalization dilemma [1-3].

There are four major factors causing the "marginalization" of English and American literature courses: First, the settings of college English curriculum fix to the career direction, such as the legal English, news English, tourism English, business English and other practical purposes. Second, English and American literature courses involve a wide range of knowledge, including literary introduction, English literature, literary criticism, which demands students to read the original English and American literature, which poses a great difficulty for most students to actively and effectively learn the courses. Third, there is a lack of systematic and holistic consideration concerning the importance of the courses and the role it plays in cultivating students' cross-culture awareness. Fourth, there is a severe shortage of qualified teachers for the courses which results in the poor teaching quality.

Many domestic and foreign experts have done a lot of research regarding the marginalization of English and American literature. Gunzhang pointed out that educational thinking should be directed to find the causes in addition to the social environment. Cheng Aimin has investigated the current situation of English and American literature teaching in China. Shi Huifeng reported the way to use multimedia courseware to promote the reform of English and American literature teaching. These researches are mainly from teachers view to explore the teaching mode, and it's very rare to explore the problem from the students' angle [4, 5]. Based on the students' needs and understanding, this research serves to analyze the present situation of English and American literature teaching and learning in Chinese colleges, and provides a reference for the teaching reform of the courses.

\section{The Connotation and Characteristics of We-Media}

The we-media is a new form of media centered in an individual armed with a smart phone, which transmits and receives digital information in a free and timing way, the individual is the operator of 
the we-media. It takes forms such as blog, micro-blogging, QQ, Wechat, forum and other online community. The media has the following features: the dissemination of the main body to the center, the strong communication mode of interaction, the high speed of transmission and free communication content. Since the above characteristics of the media, it subverts the traditional media information production, editing and dissemination, and brings teaching reform in a certain sense [6-9]. There are four main reasons why we should introduce we-media in the teaching of English and American literature:

(1) we-media has the advantages of the perfect information, the all-round perspective and the whole process in English and American literature teaching;

(2) we-media will bring the teaching changes in teaching and learning of English and American literature;

(3) strong link can be built between teachers and students in the we-media environment;

(4) we-media involves both teachers and students in the whole process of teaching with no limit.

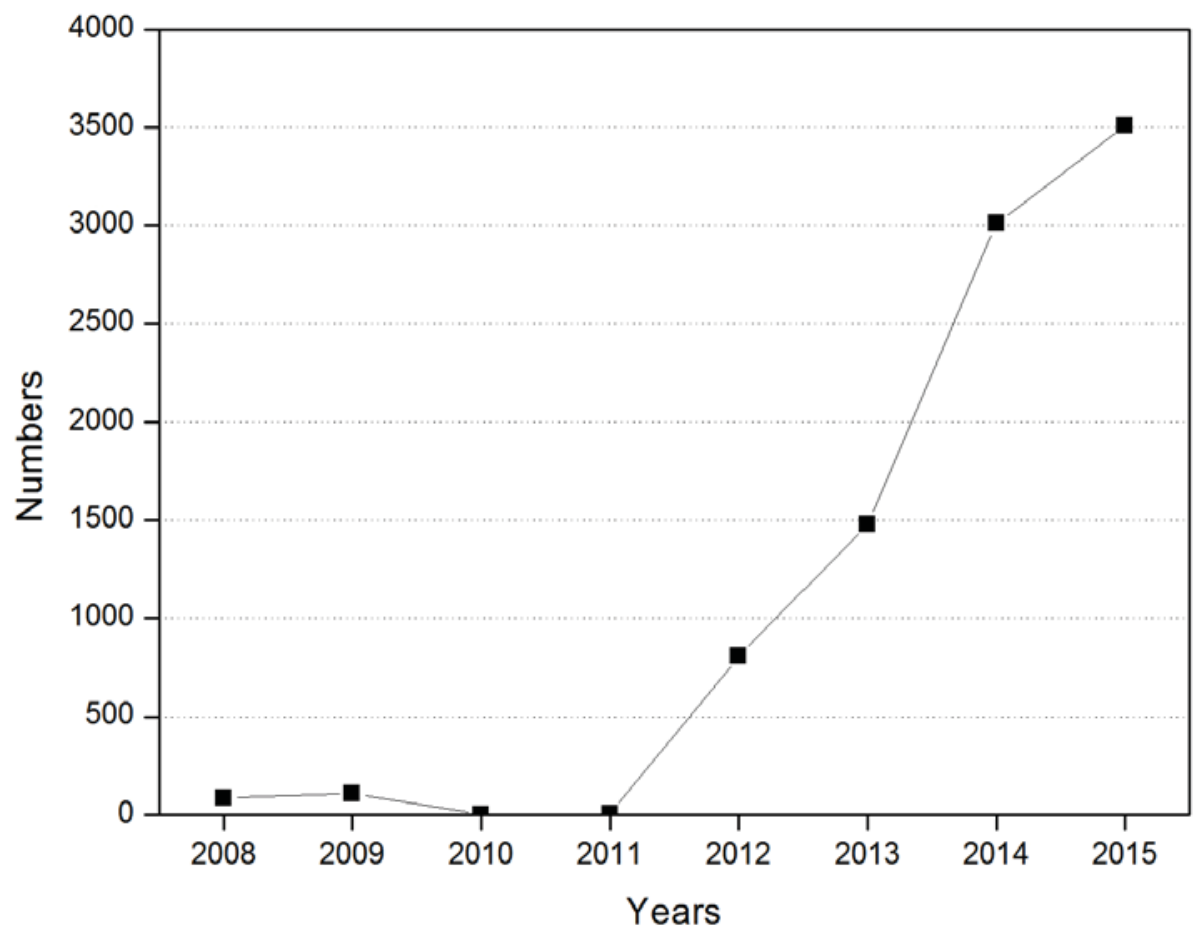

Fig. 1. Domestic Chronological Survey from We-media Research.

Fig. 1 illustrates the chronological survey from we-media research from 2008 to 2015 and the media research increased year by year, especially the blowout trend begun in 2011. Since 2010, the micro blogging marketing has been hotter and hotter with the diversification of we-media. Blog, the main media form, has developed into micro blogging, together with the emergence of micro-film and We-Chat.

\section{Questionnaires and results of English and American literature learning}

From the questionnaire, we can understand the current situation of students' English and American literature learning and the inadequacy in English and American literature teaching. First of all, questionnaires of English and American literature learning status among English college students are made, and the questionnaire are focused on two classes of students majoring in English. A total of 100 questionnaires are sent and 88 valid questionnaires collected. The content of the questionnaire involves: (1) the understanding of English and American literature curriculum; (2) the setting of English and American literature and classroom teaching problems; (3) the effects of multimedia technology in the teaching of English and American literature;(4) the difficulty and breakthrough for 
English and American literature courses; (5) the situation of English and American literature self-learning. The Results of questionnaire is shown in table 1.

In the survey, it is found that students are not very interested in the course before they are formally exposed to the English and American literature program. However, most of the students have a clear understanding of the importance and necessity for English and American literature courses after learning. Besides, they hope to gain much from the English and American literature courses.

Table 1.Results of questionnaire

\begin{tabular}{c|c|c|c|c}
\hline Options & $\mathrm{A}$ & $\mathrm{B}$ & $\mathrm{C}$ & $\mathrm{D}$ \\
\hline $\begin{array}{c}\text { Impression } \\
\text { of English and } \\
\begin{array}{c}\text { American } \\
\text { literature }\end{array}\end{array}$ & Not practical & $\begin{array}{c}\text { Difficult and } \\
\text { afraid }\end{array}$ & $\begin{array}{c}\text { Unknown and } \\
\text { puzzled }\end{array}$ & Interesting \\
\cline { 2 - 5 } & $17.65 \%$ & $20.74 \%$ & $30.51 \%$ & $31.10 \%$ \\
\hline $\begin{array}{c}\text { Dedire gain } \\
\text { from this } \\
\text { courses }\end{array}$ & $\begin{array}{c}\text { Better understanding } \\
\text { of English and } \\
\text { American history and } \\
\text { culture }\end{array}$ & $\begin{array}{c}\text { Improve English } \\
\text { literature } \\
\text { translation }\end{array}$ & $\begin{array}{c}\text { Improve listening } \\
\text { and daily dialogue }\end{array}$ & $\begin{array}{c}\text { independent } \\
\text { reading of } \\
\text { newspaper and } \\
\text { articles }\end{array}$ \\
\cline { 2 - 5 } & $50.87 \%$ & $26 \%$ & $1.98 \%$ & $21.15 \%$ \\
\hline $\begin{array}{c}\text { Teaching } \\
\text { effects of } \\
\text { mutilmedia }\end{array}$ & Very good & Good & Not bad & No effect \\
\cline { 2 - 5 } & $25.76 \%$ & $45.12 \%$ & $26.23 \%$ & $2.89 \%$ \\
\hline
\end{tabular}

Through the investigation of the current situation of students' English and American literature courses, we can understand the reasons why English and American literature curriculum linked to the current reality. The students were very impressed with the beautifully produced courseware. However, most students believe that participation in the literature classroom in general is poor owing to lack of multimedia courseware. Therefore, how to effectively use multimedia courseware, and make it conducive to strengthen the interactive teaching is a focus in the future reform.

\section{Teaching Model Construction in We-Media Environment}

In order to test the effect of network we media assisted English and American literature teaching, two parallel classes were experimented. Class One was as an experimental class, and was in the multimedia classroom for a year of we-media network-assisted teaching. The main methods employing we-media are shown in Fig. 2. There are two aspects in constructing English and American literature course. Teachers can use innovative teaching models in classroom and encourage students to learn English and American literature out of the classroom. The "Class two" was taught in the English and American literature course via the network and teachers and students blogs $[10,11]$. 


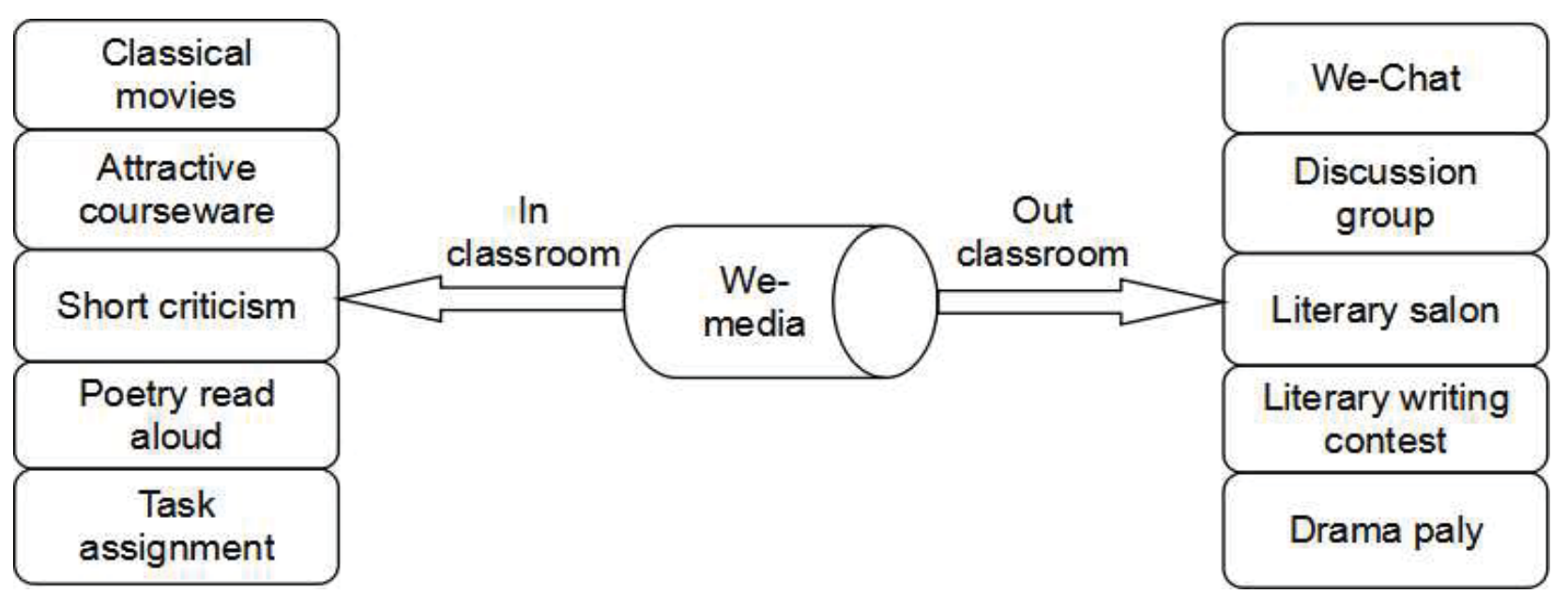

Fig. 2 The construction process of English and American literature courses using we-media

The teachers design research topics in the rich network resources, and students choose their own research questions depending on their interest. The results of the study are submitted in a book report or paper form. Students are required to read at least 2 literary works one semester and write more than one paper. Then group research is carried out. The class is divided into several study groups, and the group leader records learning activities. For example, poetry can be adapted into prose, or a chapter of a novel can be adapted into a play. In addition, the results of information technology of each group should be submitted and uploaded to the sites of course learning. This is intended to enhance the interaction between teachers and students and help students form a more intuitive perspective to understand the charm of literature. Class Two is taught in a traditional way and underwent non-multimedia mode of English and American literature teaching [12].

At the end of the semester, the unified proposition examination and questionnaire were performed to understand the students' learning situation and the teaching effect. The students in the control classes and the experimental classes began to learn English and American literature from zero in the beginning, they start from the same point. The test scores at the end of the semester had some comparative analysis from the scientific view. The quantitative data analysis is based on SPSS software [13]. The score results are shown in Fig. 3. The test scores of Class One are apparently high and the teaching effects are obviously better than that of Class Two.

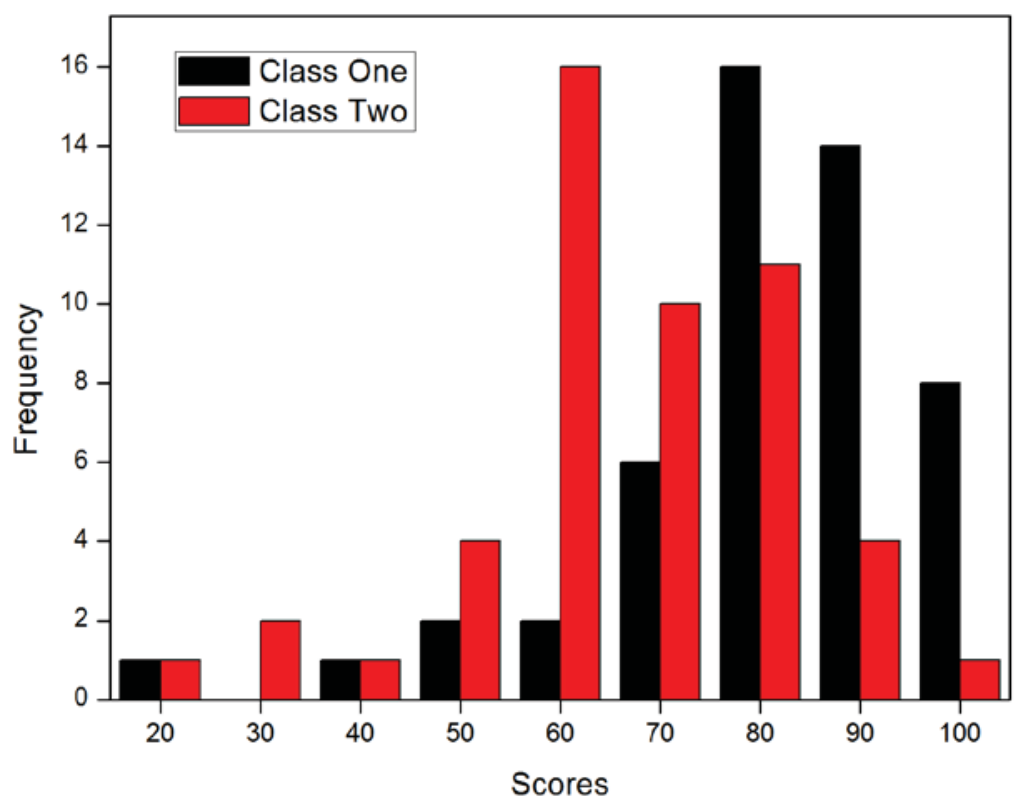

Fig. 3.The score results of the two classes. 
The outcome of the multimedia-assisted English and American literature teaching experiment is of great importance in curriculum reform and in fully mobilizing the interest and enthusiasm of teachers and students alike. It also helps to save the English and American literature curriculum out of the plight of marginalization.

In addition, the way that teachers evaluate students' mastery of English and American literature changes greatly. The combination of formative evaluation and final evaluation is no longer limited to written examination. A flexible, multi-sided, objective and fair curriculum evaluation is in real, which helps to reinforce students understanding in English and American literature and western culture. Thus students' creativity and learning motivation for English and American literature can be stimulated.

\section{Summary}

The development of multimedia and network technology provides a broad space for studying English and American literature and western culture. Students will not be lost in the massive network resources if they bear in mind a clear task and objective. In addition, this open learning method also challenges the teachers' knowledge and skills of English and American literature. Teachers of English and American literature should not only learn Chinese and western literature, but also use multimedia and network technology to improve and adjust their teaching method. Students in the new teaching model can cultivate their ability to appreciate the essence of English literature and a mastery of the courses. This innovation of English and American literature teaching model utilizing we-media opens a new era in English and American literature teaching.

\section{Acknowledgement}

This work is supported by Social Science Project of Jiangxi Province (13WX321).

\section{References}

[1] Swinfen A. In defence of fantasy: a study of the genre in English and American literature since 1945[M]. Routledge, 1984.

[2] Crawford R. Devolving English Literature[J]. The Scriblerian and the Kit-Cats, 1994, 26(2): 222.

[3] Deuze M. What is journalism? Professional identity and ideology of journalists reconsidered[J]. Journalism, 2005, 6(4): 442-464.

[4] Phillips K. Manipulating Masculinity: War and Gender in Modern British and American Literature[M]. Springer, 2016.

[5] Lefebvre M, Renard J. The Circulation of Scientific Articles in the Sphere of Web-Based Media: Citation Practices, Communities of Interests and Local Ties[J]. PloS one, 2016, 11(7):23-25.

[6] Poore M. Using social media in the classroom: A best practice guide[M]. Sage, 2015.

[7] Xiang D. China's image on international English language social media[J]. Journal of International Communication, 2013, 19(2): 252-271.

[8] Bowman S, Willis C. We media[J]. How audiences are shaping the future of news and information, 2003.

[9] Bowman S, Willis C. We media[J]. How audiences are shaping the future of news and information, 2003.

[10] Murnaghan F D. The compressibility of media under extreme pressures[J]. Proceedings of the National Academy of Sciences, 1944, 30(9): 244-247.

[11]Xiang D. China's image on international English language social media[J]. Journal of International Communication, 2013, 19(2): 252-271.

[12]Popular culture, pedagogy and teacher education: International perspectives[M]. Routledge, 2014.

[13]Field A. Discovering statistics using IBM SPSS statistics[M]. Sage, 2013. 